ISSN : 2303-1514 | E-ISSN : 2598-5949

\title{
DEVELOPING BILINGUAL POP-UP BOOK MEDIA ON THE MATERIAL ABOUT AYAM JAGO BARU FAIRY TALES FOR STUDENTS' SPEAKING SKILLS
}

\author{
Anisa Zahara Darmawati ${ }^{1}$, Rina Yuliana ${ }^{2}$, Sundawati Tisnasari ${ }^{3}$ \\ 1,2,3 Universitas Sultan Ageng Tirtayasa, Serang, Indonesia \\ ${ }^{1}$ anisazahara75@gmail.com ${ }^{2}$ rinayuliana@untirta.ac.id ${ }^{3}$ sundawati_tisnasari@untirta.ac.id
}

PENGEMBANGAN MEDIA POP-UP BOOK DWIBAHASA PADA MATERI DONGENG
AYAM JAGO BARU TERHADAP KETERAMPILAN BERBICARA SISWA

\begin{tabular}{|c|c|}
\hline ARTICLE HISTORY & ABSTRACT \\
\hline $\begin{array}{l}\text { Submitted: } \\
23 \text { September } 2020 \\
23^{\text {rd }} \text { September } 2020\end{array}$ & $\begin{array}{l}\text { Abstract: This research aimed to determine the steps for the development and feasibility of } \\
\text { bilingual Pop-up Book learning media for fairy tale material. The research method was } \\
\text { Research and Development (R\&D) method, referring to Borg and Gall model adapted by } \\
\text { Sugiyono. This model consisted of } 10 \text { stages (1) potentials and problems (2) data collection (3) } \\
\text { product design (4) design validation (5) design revision (6) small group product trials (7) } \\
\text { design revision (8) testing large group products (9) final stage product revision (10) mass } \\
\text { production. However, in this study it was only limited to } 6 \text { stages. Expert validation was } \\
\text { carried out by material experts, linguists, and media experts. The subjects of this research were } \\
\text { grade III students at SDN Unyur, totaling } 10 \text { students for limited product trials. The results } \\
\text { showed that the percentage of material expert validation was } 79 \% \text { with feasible category; the } \\
\text { linguist validation score was } 79 \% \text { with feasible category; the media expert validation score } \\
\text { was } 89 \% \text { with very feasible category; and the assessment score in limited trialswas } 82 \% \text { with } \\
\text { very good category. Based on the research results, it was concluded that bilingual pop-up book } \\
\text { media was suitable for learning to read fairv tales. }\end{array}$ \\
\hline
\end{tabular}

Keywords: developt media, bilingual pop-up book, fairy tales

Accepted:

22 Desember 2020

$22^{\text {nd }}$ December 2020

Published:

16 Februari 2021

$16^{\text {st }}$ february 2021
Abstrak: Penelitian ini sesuai dengan rumusan masalah bertujuan untuk mengetahui langkahlangkah pengembangan dan kelayakan media pembelajaran Pop-up Book dwibahasa dengan materi dongeng. metode penelitian yang digunakan adalah metode Research and Development $(R \& D)$, dengan mengacu pada model pengembangan Borg dan Gall yang dikembangkan oleh Sugiyono. Model ini terdiri dari 10 tahap (1) potensi dan masalah (2) pengumpulan data (3) desain produk (4) validasi desain (5) revisi desain (6) uji coba produk kelompok kecil (7) revisi desain (8) uji coba produk kelompok besar (9) revisi produk tahap akhir (10) produksi massal. Namun pada penelitian ini hanya dibatasi sampai 6 tahap. Validasi ahli dilakukan oleh ahli materi, ahli bahasa, dan ahli media, dengan subjek penelitian yaitu siswa kelas III SDN Unyur yang berjumlah dan diambil 10 siswa untuk uji coba produk terbatas. Dari data yang diperoleh skor validasi ahli materi mendapatkan persentase $79 \%$ dengan kategori layak, skor validasi ahli bahasa mendapatkan persentase $79 \%$ dengan kategori layak, skor validasi ahli media mendapatkan persentase sebesar $89 \%$ dengan kategori sangat layak, dan skor penilaian dalam uji coba terbatas mendapatkan persentase $82 \%$ dengan kategori sangat baik. Berdasarkan hasil penelitian dapat disimpulkan bahwa media pop-up book dwibahasa layak digunakan dalam pembelajaran membaca dongeng.

Kata Kunci: pengembangan media, pop-up book dwibahasa, dongeng

\section{CITATION}

Darmawati, A. Z., Yuliana, R., \& Tisnasari, S. (2021). Developing Bilingual Pop-Up Book Media on the Material about Ayam Jago Baru Fairy Tales for Students' Speaking Skills. Primary: Jurnal Pendidikan Guru Sekolah Dasar, 10 (1), 16 - 30. DOI: http://dx.doi.org/10.33578/jpfkip.v10i1.8044 


\section{PENDAHULUAN}

Pembelajaran bahasa Indonesia di sekolah dasar (SD) bertujuan mengembangkan keterampilan dasar siswa meliputi, baca, tulis dan hitung. Empat keterampilan bahasa Indonesia merupakan hal yang sangat penting dalam kehidupan yang terdiri atas aspek keterampilan menyimak, keterampilan berbicara, keterampilan membaca dan keterampilan menulis. Adapun keterampilan berbicara memiliki peran penting dalam kehidupan. Karena dengan berbicara seseorang bisa menyampaikan informasi atau maksud keinginan kepada orang lain. Adapun keterampilan berbicara erat kaitannya dengan kegiatan bercerita hal ini untuk melatih siswa dalam mengungkapkan suatu gagasan dan mengembangkan kosakata lewat sebuah cerita dengan berdasarkan pengetahuan, pengalaman, serta ide imajinasi siswa. Berbicara bertujuan menumbuhkan kemampuan yang baru bagi anak. Membuka wawasan anak, melatih anak untuk pintar berkomunikasi, mengembangkan bahasa anak, mengembangkan perbendaharaan kata dan tata bahasa, serta membantu dalam persiapan untuk membaca dan menulis. Pernyataan tersebut selaras dengan pembelajaran bahasa Indonesia di sekolah dasar menurut Susanto (2013:24) Salah satu keterampilan yang diharapkan dimiliki oleh siswa dari sekolah dasar ini adalah keterampilan berbahasa yang baik, karena bahasa merupakan modal terpenting bagi manusia.

Pelestarian nilai-nilai sejarah mengenai bahasa daerah khususnya daerah Banten dapat dilestarikan melalui media pembelajaran, media pembelajaran merupakan alat bantu dalam proses belajar mengajar. Segala sesuatu yang dipergunakan untuk merangsang pikiran, perasaan, perhatian dan kemampuan atau keterampilan pembelajaran sehingga dapat mendorong antusias atau kreativitas dalam belajar. Dengan adanya media pembelajaran juga dapat digunakan oleh guru agar kegiatan belajar berlangsung secara efektif. Menurut Association for Educational Communications
Technology (AECT) di Amerika yang dikutip oleh Arsyad (2002:3) "media pendidikan ialah segala bentuk saluran yang digunakan orang untuk menyalurkan pesan atau informasi." Berdasarkan fakta dilapangan di SDN Unyur pada kelas III bahwasannya, pemanfaatan media pembelajaran yang digunakan pada setiap proses pembelajaran di sekolah dasar khususnya dalam materi dongeng masih sangat kurang dan pada saat guru meminta siswa untuk membacakan dongeng tetapi siswa cenderung malu dan tidak mau untuk membaca dongeng sehingga pada saat membaca tidak terdengar oleh siswa yang lain, ketika diminta mengkomunikasikan isi dari dongeng tersebut siswa belum mengerti tentang apa yang dibacanya.

Salah satu media pembelajaran yang efektif untuk mengembangkan keterampilan berbicara dengan menggunakan media pop-up dwibahasa. Media pop-up dwibahasa merupakan sebuah buku yang memiliki bagian yang dapat bergerak atau memiliki unsur 3 dimensi. Sekilas pop-up hampir sama dengan origami dimana kedua seni ini mempergunakan teknik melipat kertas. Walau demikian origami lebih memfokuskan diri pada menciptakan objek atau benda sedangkan pop-up lebih cenderung pada pembuatan mekanis kertas yang dapat membuat gambar tampak secara lebih berbeda baik dari sisi perspektif/dimensi, perubahan bentuk hingga dapat bergerak. Menurut Nisaurrasyidah (2018: 95-110) Salah satu cara yang efektif untuk mengawal tumbuh kembang pola piker, melatih otak dan meningkatkan komunikasi anak ke arah yang positif yaitu dengan mengakrabkan dan menyibukkan anak dengan belajar tanpa menghilangkan waktu bermainnya. Buku bergambar termasuk buku ringan yang dapat menghibur sekaligus mendidik anak. Buku bergambar berbentuk pop-up menjadi salah satu bentuk buku cerita yang lebih diminati anak karena tampilannya yang menarik. Menurut Zubaidah (2003: 9) menyatakan bahwa pengertian membaca permulaan atau membaca awal lebih 
menekankan pada pengenalan dan pengucapan lambang-lambang bunyi yang berupa huruf, kata dan kalimat dalam bentuk sederhana. Tujuan membaca permulaan untuk anak usia dini 5-6 tahun mengacu pada Peraturan Menteri Pendidikan Nasional Nomor 58 (2009: 10) dalam Ulfah (2017), tentang Standar Pendidikan Anak Usia Dini yaitu anak dapat berkomunikasi secara lisan, memiliki perbendaharaan kata, serta mengenal simbolsimbol untuk persiapan membaca. Dalam bukunya Yuliani (2012) yang mengutip pernyataan dari Mayesty (1990) dalam Fitroh (2015) mengatakan bahwa seorang anak yang bermain adalah suatu kegiatan yang dilalukan sepanjang hari karena bagi anak bermain adalah hidup mereka dan hidup adalah permainan. Anak usia dini tidak membedakan antara bermain, belajar dan bekerja, sehingga bermain adalah salah satu cara anak untuk belajar. Pop Up dwibahasa merupakan buku yang menampilkan halaman-halaman buku yang di dalamnya terdapat lipatan gambar yang dipotong yang membentuk lapisan tiga dimensi yang dapat pula digerakkan sehingga tidak membosankan pembacanya. Peneliti bermaksud memanfaatkan media buku cerita pop-up sebagai salah satu solusi untuk mengatasi masalah rendahnya kemampuan siswa dalam berbicara. Sebuah gambar merupakan sarana yang baik untuk memancing, mendorong atau memotivasi siswa untuk berbicara. Indonesia kaya akan cerita tradisi rakyat. Cerita rakyat yang berkembang pada dasarnya penuh dengan halhal yang mendidik dan sarat akan pesan moral, seperti nilai moral individual, nilai moral sosial serta nilai moral religi. Pesan-pesan moral ini dapat dijadikan sebagai pembentuk karakter bangsa. Selain itu cerita rakyat mampu menambahkan kemampuan berbahasa dan meningkatkan apresiasi terhadap karya sastra Ifadhah, dkk (2015: 1) dalam Hadi (2018).

Bercerita dunia khayal memang menyenangkan. Salah satu cerita khayal adalah dongeng. Dongeng merupakan cerita yang biasanya berisi tentang khayalan dan mengandung pesan moral tinggi. Ada beberapa jenis dongeng, salah satunya yaitu dongeng binatang. Menurut Danajaja (2012) dalam Hariguna (2017) menyatakan bahwa dongeng binatang merupakan dongeng yang aktornya adalah binatang yang dapat berbicara dan berperilaku layaknya manusia. Pop-up book berperan penting dalam sebuah media pembelajaran yaitu dengan cara menyajikan materi atau pesan dengan kemasan yang lebih menarik, berupa gerakan-gerakan tak terduga yang muncul pada setiap halaman ketika dibuka, mampu memberikan pengalaman visual kepada pembaca untuk menikmati kegiatan belajarnya. Berdasarkan karakteristik buku pop-up dapat dirumuskan bahwa, buku рор-up sangat efektif apabila digunakan sebagai media pembelajaran dalam meningkatkan semangat dan ketertarikan siswa pada proses belajar, terutama materi yang mengharuskan siswa untuk membaca dan berbicara. Ditambah lagi dengan adanya dwibahasa yaitu bahasa Indonesia dengan bahasa Jawa Banten yang akan membuat siswa menjadi lebih mengenal bahasa daerah. Dengan bercerita maka siswa dapat secara langsung berbicara dengan menggunakan bahasa daerah. Maka dengan begitu dapat merangsang siswa agar lebih melestarikan bahasa daerah.

\section{KAJIAN TEORI}

Setiap proses pembelajaran, guru memerlukan media untuk membantu kegiatan belajar mengajar di kelas agar lebih efisien dan materi yang akan disampaikan lebih mudah dipahami oleh peserta didiknya. Media yang membantu kegiatan guru ini disebut dengan media pembelajaran. Menurut AECT (1997) yang dikutip kembali oleh Sanjaya (2016:57), Media adalah sebuah organisasi yang bergerak dalam teknologi pendidikan dan komunikasi, mengartikan media sebagai segala bentuk yang digunakan untuk proses penyaluran informasi. Sejalan dengan pendapat Jamaludin (2018:124), media adalah alat perantara atau pengantar di dalam melakukan proses 
pengajaran. Sedangkan menurut Hosnan (2016:111), Media adalah channel (saluran) kerena pada hakikatnya media telah memperluas atau memperpanjang kemampuan manusia untuk merasakan, mendengar dan melihat batas-batas jarak, ruang, dan waktu tertentu. Dengan bantuan media, batas-batas itu hampir tidak ada. Kemp \& Dayton (1985) dalam Dewanti (2018) mengungkapkan bahwa media memenuhi tiga fungsi utama yakni memotivasi, menyajikan informasi dan memberi instruksi. Berdasarkan uraian tersebut, fungsi dari penggunaan media pembelajaran antara lain sebagai alat untuk menarik perhatian siswa, menyampaikan materi pembelajaran, serta membantu siswa untuk memahami materi yang dipelajari.

Dari pemaparan pendapat di atas bahwa media pembelajaran adalah teknologi yang secara fisik digunakan untuk menyampaikan isi materi pengajaran serta merupakan sarana komunikasi atau teknik yang digunakan guru untuk menyampaikan materi kepada peserta didik. Adapun fungsi media pembelajaran menurut Hosnan (2014:129) sebagai berikut :

a. Membantu memudahkan belajar bagi siswa atau mahasiswa dan membantu memudahkan pengajaran bagi guru atau dosen.

b. Memberikan pengalaman lebih nyata (yang abstrak menjadi konkret).

c. Menarik perhatian siswa lebih besar (jalan pelajaran tidak membosankan).

d. Semua indera murid dapat diaktifkan, kelemahan satu indera dapat diimbangi oleh indera yang lain.

e. Lebih menarik perhatian dan minat murid dalam belajar.

f. Dapat membangkitkan dunia dengan realitanya.

Media pembelajaran memiliki banyak jenis dengan materi dan bidang masing-masing pelajaran. Menurut Schramm dalam Muhson (2010:5) mengkategorikan media dari dua segi: dari segi kompleksitas dan besarnya biaya dan menurut kemampuan daya liputannya.
Media pop-up adalah media yang berupa halaman menyerupai buku dan berisikan gambar-gambar yang menyerupai barang nyatanya yang berkaitan dengan materi yang akan diajarkan. Media pop up media pembelajaran tiga dimensi, yang bisa di lihat dari sisi manapun. Media pop up merupakan sebuah alat peraga tiga dimensi yang dapat menstimulasi imajinasi anak serta menambah pengetahuan sehingga dapat mempermudah anak dalam mengetahui penggambaran bentuk suatu benda, memperkaya perbendaharaan kata serta meningkatkan pemahaman anak. Menurut Febrianto (2016:148) "Pop Up merupakan jenis buku atau kartu yang didalamnya terdapat lipatan gambar yang dipotong dan muncul membentuk lapisan tiga dimensi ketika halaman tersebut dibuka" Sama halnya dengan Bluemel dan Taylor dalam Haryati (2017:570) mengatakan pop-up book adalah sebuah buku yang menampilkan potensi untuk bergerak dan interaksinya melalui penggunaan kertas sebagai bahan lipatan, gulungan, bentuk, roda atau putarannya. Sejalan dengan menurut Dzuanda dalam Haryati (2017:570) menjelaskan bahwa pop-up book adalah sebuah buku yang memiliki bagian yang dapat bergerak atau memiliki unsur 3 dimensi serta memberikan visualisasi cerita yang lebih menarik, mulai dari tampilan gambar yang dapat bergerak ketika halamannya dibuka.

Dari pendapat di atas dapat disimpulkan bahwa media Pop Up merupakan buku yang menampilkan halaman-halaman buku yang di dalamnya terdapat lipatan gambar yang dipotong yang membentuk lapisan tiga dimensi yang dapat pula digerakkan sehingga tidak membosankan pembacanya.

Menurut Priyono (2006) dalam Ardini (2012:48) berdasarkan jenis cerita dongeng diklasifikasikan ke dalam lima macam : (1) legenda, (2) fabel, (3) sahibul hikayat, (4) mite, (5) cerita rakyat. Legenda adalah dongeng yang berkisah tentang asal mula terjadinya suatu tempat, tradisi, dan lain sebagainya. Sebagai contoh, legenda berdirinya Candi 
Prambanan. Fabel adalah cerita tentang binatang dengan sisipan pesan moral. Sebagai contoh, kisah Lumba Lumba dan Hiu Mulut Lebar. Sahibul Hikayat adalah cerita tentang tokoh dengan tujuan untuk meneladani tokoh yang diceritakan dalam dongeng tersebut, sebagai contoh kisah para sahabat nabi. Mite adalah cerita yang menjelaskan tentang fenomena sosial yang alami atau takdir manusia dan interaksi manusia dengan supranatura, sebagai contoh dongeng tentang Dewi Sri atau Dewi Padi. Cerita rakyat adalah cerita yang diceritakan secara turun-temurun dan merupakan sebuah kebudayaan, sebagai contoh kisah Bawang Merah dan Bawang Putih (2008).

Bahasa merupakan bagian penting dalam kehidupan. Dengan adanya bahasa, satu individu dengan individu lain akan saling terhubungkan melalui proses berbahasa. Menurut Arifuddin (2010: 142) pembelajaran dwibahasa (bilingual) yang diajarkan sejak dini memiliki manfaat untuk mengembangkan kecerdasan kognitif anak, dan mengenalkan anak dengan budaya luar yang lebih majemuk. Selain itu, banyak studi yang memperlihatkan bahwa anak-anak belajar bahasa kedua lebih mudah dan lebih fasih dibandingkan orang dewasa. Sedangkan sejalan dengan Kamus besar bahasa Indonesia bahwa bilingual sebagai kemampuan memakai dua bahasa dengan baik dan bersangkutan dengan atau mengandung dua bahasa. Menurut Hurlock dalam Astuti (2017:113) dwi bahasa atau bilingualism adalah kemampuan menggunakan dua bahasa dan kemampuan ini tidak hanya dalam berbicara dan menulis tapi juga kemampuan memahami apa yang dikomunikasikan orang lain secara lisan dan tulis. Anak yang memiliki kemampuan dwibahasa memamahami bahasa asing dengan baik seperti halnya pemahaman anak terhadap bahasa orang tuanya. Dilihat dari beberapa pendapat di atas dapat ditarik kesimpulan, yaitu dwibahasa atau bilingualism adalah suatu kemampuan dalam berbicara dengan menggunakan dua bahasa selain itu juga dapat mengenalkan anak dengan budaya serta dapat memahami bahasa asing.

\section{METODE PENELITIAN}

Penelitian ini dilakukan di SD Negeri Unyur tahun ajaran 2020/2021 dimulai dari 19 September 2019 s/d 14 September 2020. Penelitian ini merupakan penelitian pengembangan media Pop-up book dwibahasa. Metode yang digunakan dalam penelitian ini adalah penelitian dan pengembangan (research and development). Desain penelitian dan pengembangan yang akan dilaksanakan merujuk pada desain pengembangan menurut Borg dan Gall (1989) dalam Arifin (2012:127) yang telah dimodifikasi oleh Sugiyono (2014:298) meliputi 10 langkah yaitu potensi dan masalah, pengumpulan data, desain produk, validasi desain, revisi desain, uji coba pemakaian, revisi produk, uji coba produk, revisi desain, revisi produk, dan produksi masal. Dibawah ini merupakan langkahlangkah dalam penelitian dan pengembangan (R\&D) ditunjukan pada gambar sebagai berikut: 


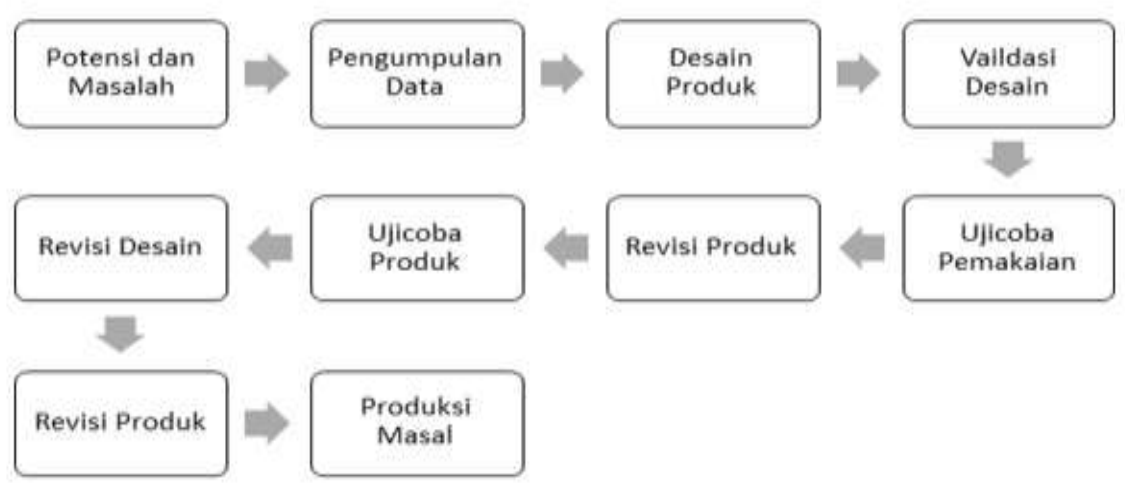

Gambar 1. Langkah-langkah desain penelitian dan pengembangan Research and Development (R\&D), Sugiyono (2014:298)

Proses pengembangan produk penelitian ini berasal karena adanya latar belakang permasalahan diatas bahwa pada pembelajaran Bahasa Indonesia khususnya materi menguraikan isi pesan suatu dongeng dalam bentuk tulisan dan lisan pada kelas III A kurang efektif dimana tidak adanya media penunjang pembelajaran dan kurangnya keterampilan menguraikan isi pesan suatu dongeng secara mandiri pada siswa di materi tersebut.

Pada tahap selanjutnya yaitu pengumpulan informasi atau data, pengumpulan data menggunakan studi literatur dari data analisis kurikulum, analisis materi, serta analisis kebutuhan. Menanggapi suatu persoalan atau peristiwa dan memberikan saran pemecahannya. Pada studi literatur ini untuk merencanakan pengembangan suatu produk berupa desain pembelajaran (RPP) yang didalamnya didukung oleh media pembelajaran yang dimanfaatkan guru dan siswa untuk menunjang pembelajaran.

Pengembangan produk yang akan dihasilkan pada penlitian ini berupa desain media pembelajaran yang didesain menggunakan gambar-gambar kartun yang dicetak (sesuai dengan gambar yang dibutuhkan dalam cerita). Dari gambar-gambar tersebut maka akan terbentuklah sebuah buku dongeng Pop-up dwibahasa yang akan didesain dengan cerita dwibahasa yang terdapat didalam buku dan juga gambargambar yang bergerak atau tiga dimensi saat dibuka bukunya.

Sebelum uji coba produk yang telah dikembangkan harus melewati beberapa tahap validasi dari uji ahli terlebih dahulu. Yang bertujuan untuk mengetahui apakah produk yang telah dikembangkan memenuhi kriteria yang telah ditentukan atau belum sama sekali. Untuk uji coba validasi pengembangan desain media pembelajaran ini dilakukan kepada 3 kategori yang telah ditentukan oleh peneliti yaitu: ahli materi, ahli bahasa dan ahli media.

Pada tahap ini dilakukan revisi setelah mendapat penilaian atau telah divalidasi oleh tim ahli. Dilakukannya pada tahap revisi desain ini yang bertujuan untuk mengetahui kelemahan-kelemahan dalam penyusunan produk dan akan diperbaiki oleh peneliti tentang desain produk tersebut. Revisi ini dilakukan untuk memberikan kritik dan saran oleh tim ahli dengan menggunakan instrumen penilaian tahap revisi telah selesai apabila produk yang telah dikembangkan dikatakan layak dan dapat diuji cobakan.

Media pembelajaran yang telah divalidasi oleh tim ahli maka akan ditindak lanjuti oleh peneliti dan akan diuji coba terbatas layak atau tidaknya maka diperlukan angket untuk mengetahui respons siswa. 
ISSN : 2303-1514 | E-ISSN : 2598-5949

tabel di bawah ini:

Tabel 1. Kisi-kisi Angket Penilaian Kelayakan Materi

\begin{tabular}{|c|c|c|}
\hline No & Aspek & Indikator \\
\hline 1. & Kesesuaian Materi & $\begin{array}{ll}\text { a. Kesesuaian materi dengan kompetensi dasar } \\
\text { b. Kesesuaian materi dengan indikator } \\
\text { c. Kesesuaian materi dengan tujuan } \\
\text { pembelajaran }\end{array}$ \\
\hline 2 & Pemberian motivasi belajar & a. Penumbuhan motivasi belajar \\
\hline & Konstekstual dan aktualitas & $\begin{array}{l}\text { a. Materi sesuai dengan konteks rangka dan } \\
\text { panca indera } \\
\text { b. Sesuai dengan kondisi sekarang }\end{array}$ \\
\hline 4 & Kelengkapan dan kualitas bahan & $\begin{array}{ll}\text { a. } & \text { Jumlah soal cukup } \\
\text { b. } & \text { Cakupan soal lengkap } \\
\text { c. } & \text { Tingkat kesulitan soal dengan materi } \\
\text { d. } & \text { Ada variasi soal }\end{array}$ \\
\hline 5 & Kedalaman materi & a. $\quad$ Materi sesuai dengan silabus \\
\hline 6 & Kemudahan untuk dipahami & $\begin{array}{l}\text { a. Materi mudah untuk dipahami } \\
\text { b. Bahasa soal mudah dipahami }\end{array}$ \\
\hline 7 & Sistematis & a. $\quad$ Keruntutan alur pikir \\
\hline 8 & Kejelasan & $\begin{array}{ll}\text { a. } & \text { Kejelasan uraian soal } \\
\text { b. } & \text { Kejelasan petunjuk belajar }\end{array}$ \\
\hline 9 & Simulasi & $\begin{array}{l}\text { a. Terdapat hukuman untuk yang tidak tepat } \\
\text { menjawab pertanyaan dengan benar }\end{array}$ \\
\hline 10 & Ketepatan evaluasi & $\begin{array}{l}\text { a. Ketepatan dalam menggunakan istilah dan } \\
\text { pertanyaan } \\
\text { b. Soal sesuai dengan teori dan konsep } \\
\text { c. Kunci jawaban sesuai dengan soal }\end{array}$ \\
\hline
\end{tabular}

Tabel 2. Kisi-kisi Angket Penilaian Kelayakan Media

\begin{tabular}{|c|c|c|c|}
\hline No & ASPEK & INDIKATOR & BUTIR SOAL \\
\hline 1 & Rekayasa media & $\begin{array}{l}\text { a. Dapat dipelihara/dikelola dengan } \\
\text { mudah } \\
\text { b. Mudah digunakan } \\
\text { c. Ketepatan memili media } \\
\text { d. Petunjuk penggunaan media jelas } \\
\text { e. Ceritanya bervariasi } \\
\text { f. Sebagian atau seluruh program media } \\
\text { dapat dimanfaatkan kembali untuk } \\
\text { mengembangkan media pembelajaran } \\
\text { lain }\end{array}$ & $1,2,3,4,5,6$ \\
\hline 2 & Komunikasi visual & $\begin{array}{l}\text { a. } \\
\text { b. Media menarik } \\
\text { c. Sederhana } \\
\text { d. Jenis huruf mudah dibaca } \\
\text { e. Ukuran huruf sesuai dan mudah } \\
\text { dibaca } \\
\text { f. Pengaturan jaraknya baik } \\
\text { g. Gambar yang disajikan menarik } \\
\text { h. Penempatan gambar tepat } \\
\text { i. Proporsi gambar seimbang }\end{array}$ & $\begin{array}{l}7,8,9,10,11,12, \\
13,14,15,16,17, \\
18,19,20,21,22\end{array}$ \\
\hline
\end{tabular}




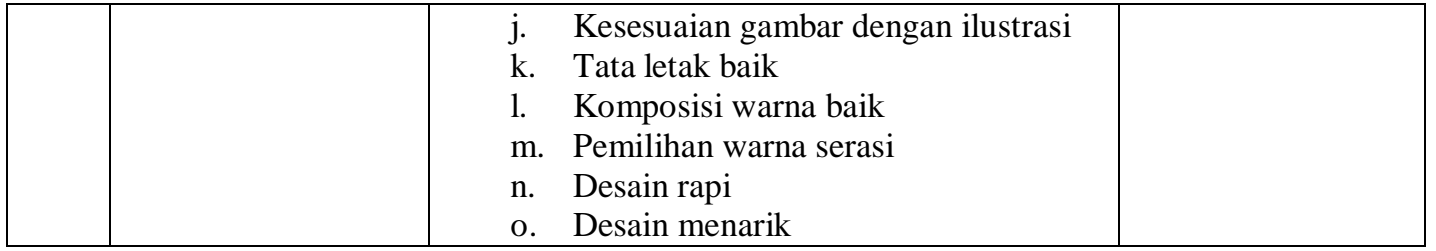

Tabel 3. Kisi-kisi Instrumen Validasi untuk Ahli Bahasa

\begin{tabular}{|c|c|c|}
\hline No & Aspek & Indikator \\
\hline \multicolumn{3}{|c|}{ Kualitas Isi dan Tujuan Media } \\
\hline 2 & Tujuan Pembelajaran & a. Kejelasan tujuan pembelajaran \\
\hline 3 & Aktivitas siswa & $\begin{array}{lll}\text { a. } & \text { Kesesuaian isi media dengan } \\
& \text { kompetensi dasar dan indikator } \\
\text { b. Kebenaran konsep materi melalui } & \\
& \text { aktivitas siswa } \\
\text { c. Kejelasan alur pembelajaran } \\
\text { d. Kesesuaian gambar dengan materi }\end{array}$ \\
\hline 4 & Penyajian & $\begin{array}{l}\text { a. Kemampuan dalam memberikan } \\
\text { interaksi langsung antara pengguna dan } \\
\text { materi pembelajaran } \\
\text { b. Ketepatan penggunaan bahasa dan } \\
\text { ketepatan pemilihan kalimat }\end{array}$ \\
\hline 5 & Pengaruh media terhadap siswa & a. Meningkatkan aktivitas belajar siswa \\
\hline \multicolumn{3}{|c|}{ Kualitas Media } \\
\hline 7 & Tampilan & $\begin{array}{l}\text { a. Pemilihan background } \\
\text { b. Pemilihan karakter pada setiap dongeng } \\
\text { c. Pemilihan dan keterbacaan tulisan }\end{array}$ \\
\hline 8 & Pengaplikasian & $\begin{array}{l}\text { a. Kualitas interaksi siswa dengan media } \\
\text { b. Kualitas gambar }\end{array}$ \\
\hline
\end{tabular}

Tabel 4. Kisi-kisi Angket Respons Peserta Didik

\begin{tabular}{|c|c|c|}
\hline No & Aspek & Indikator \\
\hline \multirow{4}{*}{1.} & \multirow{4}{*}{ Kualitas Media } & Media mudah dipahami \\
\hline & & Media dapat dimengerti \\
\hline & & Meningkatkan motivasi belajar \\
\hline & & $\begin{array}{l}\text { Gambar pada media mudah dipahami } \\
\text { dan menarik }\end{array}$ \\
\hline \multirow{4}{*}{2.} & \multirow{4}{*}{ Kualitas Materi } & Penyajian materi menarik \\
\hline & & Penggunaan bahasa \\
\hline & & Isi mudah dipahami \\
\hline & & $\begin{array}{l}\text { Materi berhubungan dengan budaya } \\
\text { Banten }\end{array}$ \\
\hline \multirow{5}{*}{3.} & \multirow{5}{*}{ ketertarikan } & Media ini membuat saya senang \\
\hline & & Media ini memotivasi untuk belajar \\
\hline & & Pembelajaran menjadi terarah \\
\hline & & Pembelajaran menjadi menyenangkan \\
\hline & & Meningkatkan motivasi untuk membaca \\
\hline
\end{tabular}




\section{HASIL DAN PEMBAHASAN}

Tahap ini diawali dengan melakukan observasi. Pada observasi tersebut didapatkan bahwa kurangnya media pembelajaran yang digunakan saat pembelajaran, sehingga materi tidak tersampaikan dengan baik kepada siswa. Tahap selanjutnya adalah melakukan wawancara tak berstruktur kepada Ibu Hayati, S.Pd selaku guru kelas III SDN Unyur. Wawancara ini dimaksudkan untuk mendapatkan informasi mengenai materi, dimana materi yang dikenankan adalah mengenai dongeng yang akan dikembangkan dalam media Pop-up Book Dwibahasa. Sementara analisis kurikulum dimaksudkan untuk melihat kesesuaian materi dengan kebutuhan penelitian. Berdasarkan hasil analisis kurikulum yang telah dilakukan, Kompetensi Dasar dan Indikator yang tepat adalah sebagai berikut:

a. Kompetensi Dasar

3.8 Menguraikan pesan dalam dongeng yang disajikan secara lisan, tulis, dan visual dengan tujuan untuk kesenangan.

4.8 Memeragakan pesan dalam dongeng sebagai bentuk ungkapan diri menggunakan kosa kata baku dan kalimat efektif.

b. Indikator

3.8.1 Mengidentifikasi pesan yang terdapat dalam suatu dongeng.
4.8.1 Menguraikan pesan yang terdapat dalam suatu dongeng yang disajikan secara lisan.

Berdasarkan hasil analisis yang telah dilakukan maka peneliti membuat suatu rancangan produk berupa media pembelajaran yang dikembangkan sesuai dengan hasil analisis sebelumnya. Media pembelajaran dalam penelitian ini bernama Pop-up Book Dwibahasa. Tahap awal pembuatan media pembelajaran Pop-up Book Dwibahasa materi dongeng ayam jago baru ini dilakukan dengan membuat Storyboard. Storyboard yang dibuat menggunakan skrip/naskah berupa cerita beralur yang disertai gambar.

Tahap desain media pembelajaran Pop-up Book dwibahasa pada mata pelajaran Bahasa Indonesia materi dongeng ayam jago baru di kelas III SDN Unyur. Langkah-langkah yang dilakukan yaitu:

a. Membuat alur cerita berdasarkan buku, cerita yang telah dibuat sesuai dengan konsep bacaan mengenai dongeng ayam jago baru, kemudian di pilih gambar yang tepat dengan ukuran A3 pemilihan gambar dengan mencari referensi gambar di internet yang sesuai dengan alur cerita.

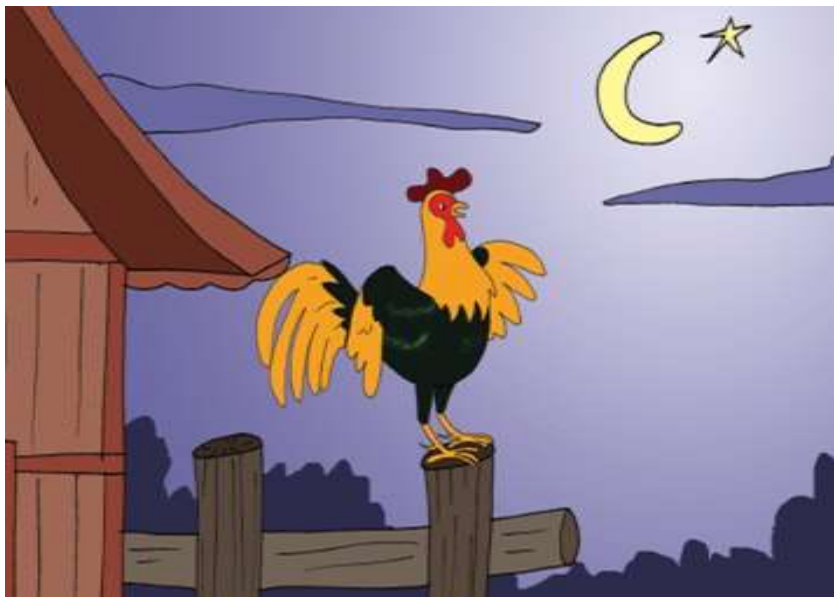

Gambar 2. Contoh Pemilihan Gambar yang Diambil Dari Internet 
ISSN : 2303-1514 | E-ISSN : 2598-5949

b. Gambar yang telah dipilih kemudian di copy ke microsoft word dan di edit, gambar diatur gelap terang dan kecocokan pada alur cerita. Gambar yang dipilih harus bernuansa cerah agar disukai anak-anak.

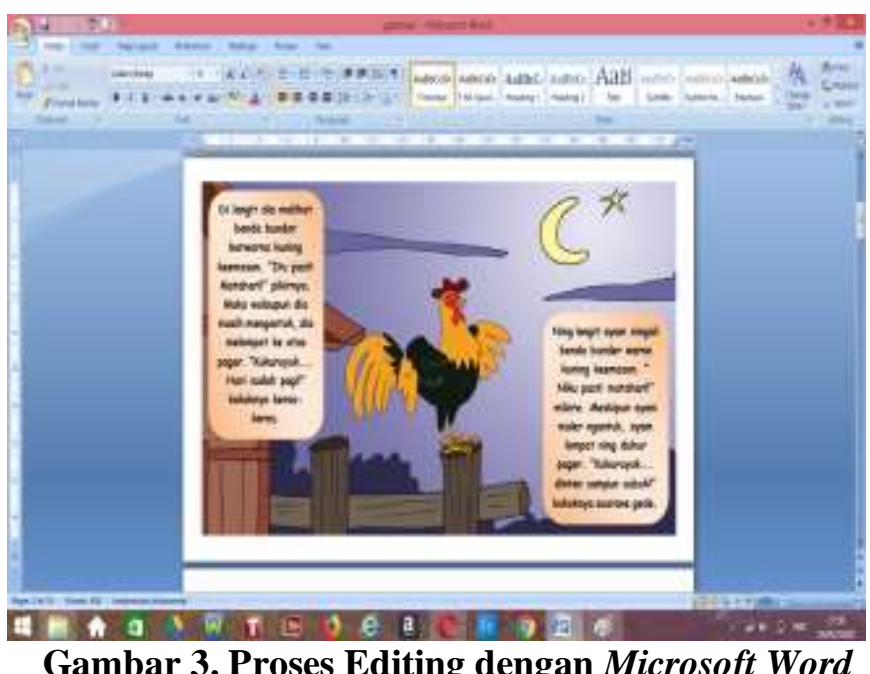

c. Setelah semua gambar telah dipilih, dilanjutkan dengan menambah shape dengan ukuran yang menarik saat dilihat

d. Setelah semua gambar sudah di edit, maka dilakukan editing gambar dengan teks dan tanpa teks, gambar yang menjadi background akan ditumpuk dengan naskah cerita dua bahasa dan gambar tokoh akan dibentuk tiga dimensi.

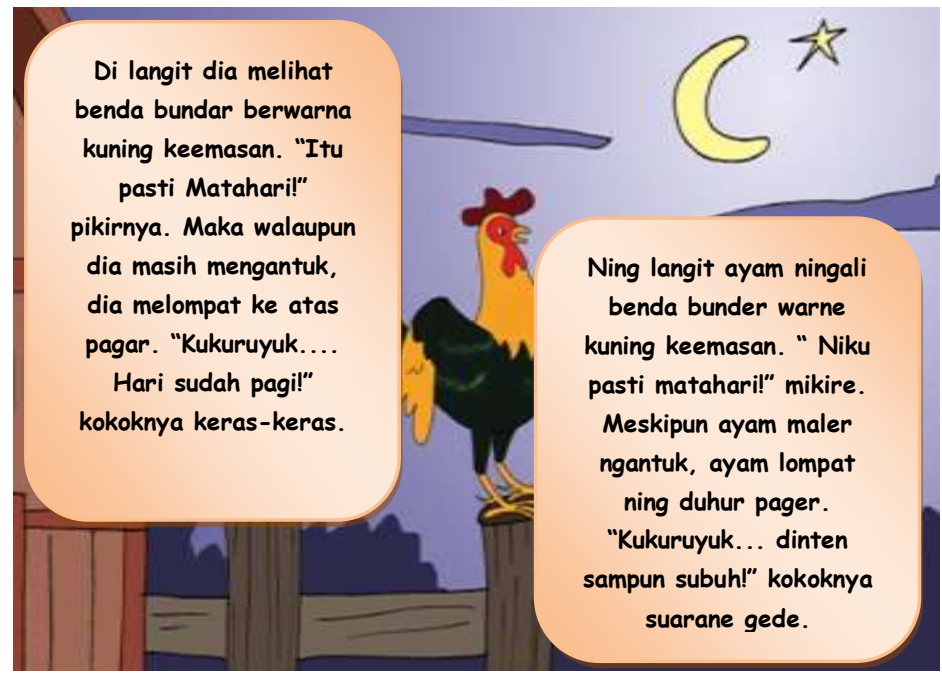

Gambar 4 . Hasil Gambar yang Telah Di Edit

e. Selanjutnya semua data di cetak dan dijadikan buku yang ketika dibuka akan timbul. 


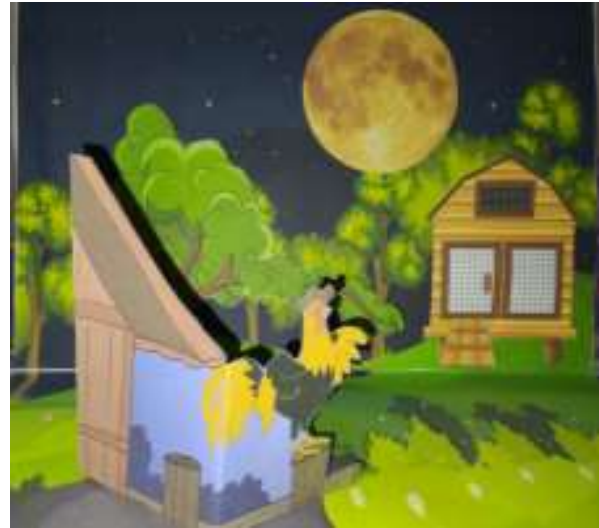

Gambar 5 . Hasil Gambar Yang Telah Dibuat Pop-Up Book

Tahap validasi/ uji ahli dilakukan untuk mengecek kelayakan media pembelajaran Popup Book dwibahasa materi dongeng ayam jago baru untuk digunakan dalam proses pembelajaran. Tahap validasi ini juga merupakan tahap menentukan apakah instrumen penilaian para ahli dan produk berupa media pembelajaran Pop-up Book Dwibahasa materi dongeng ayam jago baru yang dikembangkan sudah pantas dan layak untuk di uji cobakan atau belum. Tahap ini dilakukan dengan cara menghadirkan beberapa pakar atau tenaga ahli yang sudah berpengalaman untuk menilai produk yang dirancang. Setiap pakar diminta untuk menilai produk tersebut, sehingga dapat diketahui kelemahan dan kelebihannya. Tim ahli dalam validasi meliputi ahli media, ahli materi, dan ahli bahasa.

Tabel 5. Data Penilaian Validasi Ahli Materi

\begin{tabular}{|c|c|c|c|c|}
\hline \multirow{2}{*}{ NO } & \multirow{2}{*}{ Kriteria } & \multicolumn{2}{|c|}{ Penilaian Ahli } & Interpretasi \\
\cline { 3 - 4 } & & $\begin{array}{l}\text { Ahli } \\
\text { Materi I }\end{array}$ & $\begin{array}{l}\text { Ahli } \\
\text { II }\end{array}$ & Materi \\
\hline 1 & Aspek Pembelajaran & 97 & 92 & $94.5 \%$ \\
\hline \multicolumn{2}{|c|}{ Jumlah } & 97 & 92 & $94.5 \%$ \\
\hline \multicolumn{2}{|c|}{ NP \% } & $97 \%$ & $92 \%$ & \\
\hline \multicolumn{2}{|c|}{ Rata-rata } & \multicolumn{2}{|c|}{$94.5 \%$} \\
\hline \multicolumn{2}{|c|}{ Kategori Penilaian } & Sangat Layak \\
\hline
\end{tabular}

Berdasarkan tabel data penilaian validasi ahli materi diatas menunjukkan hasil jumlah skor penilaian kedua ahli materi dapat diperoleh persentase nilai sebesar $94.5 \%$, interpretasi layak dengan kritik dan saran.

Tabel 6. Data Penilaian Validasi Ahli Bahasa

\begin{tabular}{|c|c|c|c|c|}
\hline \multirow[t]{2}{*}{ NO } & \multirow[t]{2}{*}{ Kriteria } & \multicolumn{2}{|c|}{ Penilaian Ahli } & \multirow{2}{*}{$\begin{array}{l}\text { Interpretasi } \\
\text { Nilai \% }\end{array}$} \\
\hline & & $\begin{array}{l}\text { Ahli } \\
\text { Materi I }\end{array}$ & $\begin{array}{l}\text { Ahli Materi } \\
\text { II }\end{array}$ & \\
\hline 1 & $\begin{array}{l}\text { Ketepatan } \\
\text { Kalimat }\end{array}$ & 42 & 44 & $95.5 \%$ \\
\hline 2 & $\begin{array}{l}\text { Dialog adegan jelas } \\
\text { dan mudah ditangkkap }\end{array}$ & 18 & 16 & $85 \%$ \\
\hline
\end{tabular}


ISSN : 2303-1514 | E-ISSN : 2598-5949

\begin{tabular}{|c|c|c|c|}
\hline maknanya & & & \\
\hline Jumlah & 60 & 60 & $92.3 \%$ \\
\cline { 1 - 2 } NP \% & $92.3 \%$ & $92.3 \%$ & \multirow{2}{*|}{$92.3 \%$} \\
\hline Rata-rata & \multicolumn{2}{|c|}{$92.3 \%$} & Sangat Layak \\
\hline \multicolumn{2}{|r|}{ Kategori Penilaian } \\
\hline
\end{tabular}

Berdasarkan tabel data penilaian validasi ahli bahasa diatas menunjukkan hasil jumlah skor penilaian kedua ahli materi dapat diperoleh persentase nilai sebesar $92.3 \%$ interpretasi sangat layak dengan kritik dan saran.

Tabel 7. Data Penilaian Validasi Ahli Media

\begin{tabular}{|l|l|c|c|c|}
\hline \multirow{2}{*}{ NO } & \multirow{2}{*}{ Kriteria } & \multicolumn{2}{|c|}{ Penilaian Ahli } & $\begin{array}{c}\text { Interpretasi } \\
\text { Nilai \% }\end{array}$ \\
\cline { 2 - 4 } & $\begin{array}{c}\text { Ahli } \\
\text { Materi I }\end{array}$ & $\begin{array}{c}\text { Ahli Materi } \\
\text { II }\end{array}$ & \\
\hline 1 & $\begin{array}{l}\text { Aspek } \\
\text { Media }\end{array}$ & 23 & 25 & $96 \%$ \\
\hline 2 & Aspek Keindahan & 73 & 70 & $95.3 \%$ \\
\hline \multicolumn{2}{|c|}{ Jumlah } & 96 & 95 & $95.5 \%$ \\
\hline \multicolumn{2}{|c|}{ NP \% } & $95.5 \%$ & $95.5 \%$ & $95.5 \%$ \\
\hline \multicolumn{2}{|c|}{ Kata-rata } & Sangat Layak \\
\hline
\end{tabular}

Berdasarkan tabel data penilaian validasi ahli bahasa diatas menunjukkan hasil jumlah skor penilaian kedua ahli materi dapat diperoleh persentase nilai sebesar $95.5 \%$ interpretasi sangat layak dengan kritik dan saran.

Tabel 8. Data Hasil Respons Siswa

\begin{tabular}{|c|c|c|c|c|c|c|c|}
\hline \multirow{2}{*}{ No } & \multirow{2}{*}{ Responden } & \multicolumn{3}{|c|}{ Indikator } & \multirow{2}{*}{ Skor } & \multirow{2}{*}{$\begin{array}{l}\text { Nilai } \\
\text { Akhir }\end{array}$} & \multirow{2}{*}{ Keterangan } \\
\hline & & Media & Materi & Ketertarikan & & & \\
\hline 1 & Responden I & 20 & 13 & 18 & 51 & 85 & Sangat Setuju \\
\hline 2 & Responden II & 15 & 12 & 22 & 49 & 82 & Sangat Setuju \\
\hline 3 & Responden III & 18 & 11 & 17 & 46 & 77 & Setuju \\
\hline 4 & Responden IV & 15 & 11 & 19 & 45 & 75 & Setuju \\
\hline 5 & Responden V & 18 & 10 & 21 & 49 & 82 & Sangat Setuju \\
\hline 6 & Responden VI & 18 & 12 & 21 & 51 & 85 & Sangat Setuju \\
\hline 7 & Responden VII & 17 & 12 & 16 & 45 & 75 & Setuju \\
\hline 8 & Responden VIII & 18 & 14 & 17 & 49 & 82 & Sangat Setuju \\
\hline 9 & Responden IX & 16 & 14 & 21 & 51 & 85 & Sangat Setuju \\
\hline \multirow[t]{3}{*}{10} & Responden X & 20 & 14 & 21 & 55 & 92 & Sangat Setuju \\
\hline & Skor & 175 & 123 & 193 & 491 & 820 & \multirow[t]{2}{*}{ Sangat Setuju } \\
\hline & Nilai Akhir & $88 \%$ & $77 \%$ & $80 \%$ & $82 \%$ & $82 \%$ & \\
\hline
\end{tabular}

Dengan melihat hasil dari angket respons siswa diatas maka dapat dikatakan bahwa dengan media pop-up book dwibahasa yang telah diujicobakan mendapatkan persentase sebesar $82 \%$ dan masuk dalam kategori sangat baik. Uji coba produk 
berlangsung lancar dengan antusias siswa pada saat menggunakan media pop-up book dwibahasa. Hasil akhir dari pengembangan media ini adalah media pop-up book dwibahasa pada keterampilan berbicara siswa.

\section{Pembahasan}

Fokus penelitian ini adalah pengembangan media pembelajaran Pop-up Book dwibahasa materi dongeng ayam jago baru pada keterampilan berbicara siswa di kelas III Sekolah Dasar. Metode penelitian yang diambil merupakan penelitian dan pengembangan (research and development), yang merupakan penelitian yang menghasilkan sebuah produk yaitu media pembelajaran Popup Book dwibahasa materi dongeng pada keterampilan berbicara siswa.

Media pembelajaran Pop-up Book dwibahasa yang dikembangkan oleh peneliti menggunakan jenis Pop-up Book "Transformasi" dikarenakan pengembangan media pembelajaran Pop-up Book dwibahasa ini menunjukan perubahan bentuk serta gerakan objek secara vertikal sesuai dengan salah satu jenis yang dipaparkan oleh (Safri 2016:48). Penelitian ini berfokus pada pengembangan media pembelajaran Pop-up Book dwibahasa pada materi dongeng ayam jago baru pada keterampilan berbicara siswa.

Media pembelajaran Pop-up Book dwibahasa yang telah jadi belum menjadi produk akhir yang layak untuk diuji cobakan, karena perlu melalui tahap validasi dari 6 ahli yakni 2 ahli materi, 2 ahli bahasa, dan 2 ahli media yang terdapat revisi atau perbaikan.

Terdapat 20 butir pernyataan pada angket validitas ahli materi. Skor yang didapatkan bervariasi yaitu SS (Sangat Sesuai), S (Sesuai), CS (Cukup Sesuai), KS (Kurang Sesuai), SKS (Sangat Kurang Sesuai). Dari keseluruhan butir pernyataan pada setiap aspek, media pop-up book dwibahasa materi dongeng memperoleh skor $\mathrm{S}$ sangat banyak. Sehingga materi dianggap sudah sesuai dengan standar materi yang terdapat dalam RPP dan LKPD. Penilaian yang dilakukan oleh 2 ahli materi yaitu dengan tingkat validitas yang didapat dari hasil penilaian yakni $79 \%$ dengan integritas layak. Komponen yang dianggap layak oleh ahli materi yaitu kelayakan isi yang terdiri dari kesesuaian materi dengan KD dan pendukung materi pembelajaran. Dalam keakuratan materi masih kurang layak dan harus direvisi kembali, adapun konten materi dongeng belum/kurang sesuai dengan kebutuhan indikator pembelajaran.

Terdapat 13 butir pernyataan pada angket validitas ahli bahasa dengan skor yang didapatkan bervariasi yaitu SS (Sangat Sesuai), S (Sesuai), CS (Cukup Sesuai), KS (Kurang Sesuai), SKS (Sangat Kurang Sesuai). Dari keseluruhan butir pernyataan pada setiap aspek, media pop-up book dwibahasa materi dongeng memperoleh skor $\mathrm{S}$ terbanyak. Sehingga bahasa yang digunakan dianggap sudah sesuai dengan ejaan yang disempurnakan baik dalam aspek Bahasa Indonesia maupun aspek Bahasa Jawa Banten. Penilaian yang dilakukan oleh 2 ahli bahasa yaitu dengan tingkat validitas yang didapat dari hasil penilaian yakni $79 \%$ dengan integritas layak. Komponen yang dianggap layak oleh ahli bahasa yaitu bahasa yang digunakan sudah sesuai dengan ejaan bahasa Indonesia yang disempurnakan. Adapun dalam aspek Bahasa Jawa Banten yang belum susuai dengan ejaan yang benar dan masih harus direvisi.

Terdapat 20 butir pernyataan pada angket validitas ahli media dengan skor yang didapatkan bervariasi yaitu SS (Sangat Sesuai), S (Sesuai), CS (Cukup Sesuai), KS (Kurang Sesuai), SKS (Sangat Kurang Sesuai). Dari keseluruhan butir pernyataan pada setiap aspek, media pop-up book dwibahasa materi dongeng memperoleh skor SS terbanyak. Sehingga media yang digunakan dalam pembelajaran dianggap sudah sesuai dengan aspek rekayasa media dan aspek keindahan dari media. Penilaian yang dilakukan oleh 2 ahli media yaitu dengan tingkat validitas yang didapat dari hasil penilaian yang berbeda yakni $89 \%$ dengan integritas sangat layak. Setelah media divalidasi oleh para ahli dan direvisi sesuai saran setiap ahli kemudian media diuji cobakan pada siswa. 
Dengan melalui adanya pop-up book dwibahasa ini maka dapat terlihat anak-anak lebih antusias dan lebih berani untuk berbicara serta mengungkapkan pendapat. Selain itu media pop-up book dwibahasa ini sangat membantu guru dalam melakukan proses pebelajaran dikelas dengan media yang terlihat 3 dimensi seperti yang dikemukakan oleh Montanaro 1993 dalam Dzuanda (2009:1) mendefinisikan bahwa Pop up Book merupakan sebuah buku yang memiliki bagian yang dapat bergerak atau memiliki unsur tiga dimensi. Dari hasil penelitian dapat dikatakan bahwa media pembelajaran pop-up book dwibahasa dapat digunakan sebagai media dalam pembelajaran materi dongeng Ayam Jago Baru, dan diharapkan dapat membantu guru dalam proses pembelajaran di kelas.

\section{SIMPULAN DAN REKOMENDASI}

Berdasarkan rumusan masalah pada pengembangan media pembelajaran pop-up book dwibahasa materi dongeng ayam jago baru pada keterampilan berbicara siswa di kelas III Sekolah Dasar, maka dapat disimpulkan sebagai berikut:

a. Kelayakan media pembelajaran pop-up book dwibahasa materi dongeng ayam jago baru di kelas III sekolah dasar didapatkan dari penilaian ahli materi, ahli bahasa, ahli media. Hasil validasi pada ahli materi mendapatkan rata-rata skor akhir dengan persentase nilai ahli materi $94.5 \%$ dalam kategori sangat layak. Hasil validasi pada ahli bahasa mendapatkan rata-rata skor akhir dengan persentase nilai $92.3 \%$ dalam kategori sangat layak. Hasil validasi pada ahli media mendapatkan rata-rata skor akhir dengan persentase nilai ahli materi $95.5 \%$ dalam kategori sangat layak.

b. Hasil dari angket respons siswa pada uji coba lapangan menunjukkan kriteria sangat setuju dengan diperoleh nilai $82 \%$. Hasil penelitian menunjukkan bahwa media pop up book dwibahasa sangat tepat dan dapat digunakan dengan baik dalam proses pembelajaran pada kelas III Sekolah Dasar.

Dapat dijadikan rekomendasi sebagai pengembangan media pembelajaran berupa sumber belajar alternatif, sehingga guru akan lebih banyak berperan sebagai fasilitator bagi siswa dan membantu proses pembelajaran menjadi lebih efektif.

\section{UCAPAN TERIMA KASIH}

Terima kasih penulis ucapkan kepada Ibu Rina Yuliana, M.Pd (Universitas Sultan Ageng Tirtayasa), Ibu Sundawati Tisnasari, M. Pd (Universitas Sultan Ageng Tirtayasa), Ibu Hayati, S. Pd (SD Negeri Unyur), Peserta didik kelas III SD Negeri Unyur, serta pihak-pihak yang telah memberikan dukungan, saran, dan bantuan selama berlangsungnya penelitian ini.

\section{DAFTAR PUSTAKA}

Aditya, F. A., Minarsih, M.M., dan Warso, M. M. (2016). "Pengaruh Insentif, Komunikasi Dan Lingkungan Kerja Terhadap Kepuasan Kerja Dan Implikasinya Terhadap Produktivitas Kerja Di CV. Duta Karya Semarang". Jurnal Manajemen, 2(2), 1-10.

Ali, M. (2010). Pengembangan Media Pembelajaran Berbasis Teknologi Informasi. Jurnal Pendidikan Akuntansi Indonesia, 8, 1-10.

Arifuddin. (2010). The Friendship Analysis in The Novel 'The Kite Runner' By Khaled Hosseini. Undergraduate (S1) thesis, Universitas Islam Negeri Alauddin Makassar.

Arsyad, A. (2011). Media Pembelajaran. Jakarta: PT RAJAGRAFINDO PERSADA.

Ardini, P. P. (2012). Pengaruh Dongeng dan Komunikasi Terhadap Perkembangan Moral Anak Usia 7-8 Tahun. Jurnal Pendidikan Anak, 1, 44-58.

Dzuanda, B. (2009). Perancangan Buku Cerita Anak Pop-Up Tokoh-Tokoh Wayang Berseri "Gatotkaca". Surabaya : Desain Produk Institut Teknik Surabaya.

Fitroh, S. F., dan Sari, E. D. N. (2015). Dongeng Sebagai Media Penanaman Karakter pada Anak Usia Dini. Jurnal $P G$ PAUD Trunojoyo. 2(2).

Hadi, M. S., dkk. (2018). Peracangan Media Buku Pop-up Cerita Rakyat Rambun 
Pamenan Sumatra Barat. Jurnal FBS Universitas Negeri Padang. 1, hal 1.

Handaruni, D, dkk. (2018). Pengembangan Media Pop-up Book untuk Pembelajaran Lingkungan Tempat Tinggalku Kelas IV SDN 1 Pakunden Kabupaten Ponorogo. Jurnal JKTP, 1(3).

Haryati, K. (2006). Peningkatan Kterampilan Menulis Melalui Media Pop Up pada Siswa Kelas IVA SD N Jageran Sewon. Jurnal Pendidikan Guru Sekolah Dasar, edisi 6, 567-577.

Hosnan. (2014). Pendekatan Saintifik dan Kontekstual dalam Pembelajaran Abad 21. Bogor: Ghalia Indonesia.

Hariguna, T., dan Wijiono, A. (2017). Dongeng Ayam dan Kelinci Bersaudara Berbasis Animasi 2 Dimensi. Jurnal Telematika. 10(1).

Ida, N. (2018). Proses Visualisasi Buku Dongeng Timun Mas dengan Teknik PopUp untuk Pengembangan Kemampuan Anak. Jurnal Dakwah dan Komunikasi, 9, 95-110.

Jamaludin, U dan Rachmatullah, R. (2018). Pembelajaran Pendidikan IPS Teori Konsep dan Aplikasi Bagi Guru dan Mahasiswa. Bekasi: CV. Nurani.

Meilia, S. (2016). Pengembangan Media Belajar Pop-Up Book Pada Materi Minyak Bumi. Jurnal Pendidikan Sains Indonesia . 05(01) : 107-113.

Ria, A. (2017). Penerapan Pembelelajaran Bilingual di TK Inklusi. Jurnal Pendidikan Anak, 3, 109-123.

Sanjaya, W. (2016). Media Komunikasi Pembelajaran. Jakarta: Prenamedia Grup.

Sugiyono. (2014). Metode Penelitian Pendidikan Pendekatan Kuantitatif, Kualitatif, dan $R \& D$. Bandung: Alfabeta.

Susanto, A. (2013). Teori Belajar dan Pembelajaran di Sekolah Dasar. Jakarta: Kencana Prenadamedia Group.

Ulfah, A. A., dan Rahmah, E. (2017). Pembuatan dan Pemanfaatan Busy Book dalam Mempercepat Kemampuan Membaca untuk Anak Usia Dini di PAUD Budi Luhur Padang. Jurnal Ilmu Informasi Perpustakaan dan Kearsipan. 6(1). 